\title{
CHARACTERISTICS OF LYMPHADENITIS IN HOSPITALISED PATIENTS BANDAR LAMPUNG-INDONESIA
}

\author{
Hetti Rusmini' ${ }^{1}$ Retno Ariza², Nur Rahayu Permana Sari ${ }^{3}$ \\ ${ }^{1}$ Lecturer in Faculty of Medicine, Malahayati University, Bandar Lampung, Indonesia. Email: hetti@malahayati.ac.id \\ 2Medical Doctor in Department of Pulmonology and Respiratory Medicine-Dr. Abdoel Moeloek Hospital, \\ Bandar Lampung, Indonesia \\ ${ }^{3}$ Student in Medical Education Study Program, Malahayati University, Bandar Lampung, Indonesia.
}

\begin{abstract}
Background: Lymphadenitis is an inflammation of the lymph nodes caused by a variety of microorganisms such as Mycobacterium tuberculosis, human immunodeficiency virus (HIV), and other microorganisms. Patient characteristics lymphadenitis diverse views on the etiology, age, gender, and lymph nodes affected.

Purpose: The purpose of this study was to describe the characteristics of patients with lymphadenitis.

Methods: The design of this study is descriptive cross sectional method is done by looking at medical records of patients in Dr. H. Abdul Moeloek hospital Bandar Lampung 2015. The samples were taken using stratified random sampling technique so that 161 samples used in this study.

Results: The results showed the frequency distribution of patients with tuberculous lymphadenitis is the highest (57.14\%), lymphadenitis other microorganisms $(21.74 \%)$, and HIV lymphadenitis $(21.12 \%)$. The frequency distribution of TB lymphadenitis patient age was 15-24 years (45.7\%), patients with HIV lymphadenitis most at the age of 45-64 $(29.4 \%)$, while the age of the patient lymphadenitis other microorganisms highest in the 15-24 age $(28,6 \%)$. The frequency distribution of TB lymphadenitis gender, HIV and most were female $(58.7 \%$ and $52.9 \%)$, while the frequency distribution of the sexes in most other microorganisms lymphadenitis patients were male $(54.3 \%)$.

Conclusion: The frequency distribution locations lymphadenitis TB, HIV and other microorganisms most was the neck (regio colli) $(96 \%, 55.9 \%$ and $57.1 \%)$.
\end{abstract}

\section{Keywords: Tuberculosis lymphadenitis, HIV lymphadenitis, Other microorganisms lymphadenitis}

\section{INTRODUCTION}

Lymphadenitis is an inflammation of the lymph nodes caused by microorganisms known as lymphadenopathy (Price \& Wilson, 2005). Lymphadenopathy is enlargement of lymph nodes with a size greater than $1 \mathrm{~cm}$, (Ferrer, 1998). Lymphadenopathy is the most common symptom in patients with HIV infection, can occur at the beginning of infection manifestations or can also be found at any stage of HIV infection. At least $25 \%$ of patients with HIV / AIDS have lymphadenopathy that can be found on physical examination (Amin, et al, 2014). At present almost $95 \%$ of adult gland mycobacterial infections are caused by Mycobacterium tuberculosis and the remainder is caused by atypical mycobacterium mycobacteria (NTM). Whereas in pediatric patients $92 \%$ of cases are caused by atypical mycobacteria. In Indonesia, of the 84 lymph node aspiration cultures carried out in Hasan Sadikin Hospital successfully grown 23 cultures where 10 cultures were overgrown with
Mycobacterium tuberculosis while 13 cultures were overgrown with atypical mycobacterial (WHO, 2013).

The initial diagnosis of lymphadenitis is done with a thorough history and physical examination, hematological examination, tuberculin test, acidresistant bacillus staining, tuberculin test, radiological examination, and fine cytology needle, while for the final diagnosis is done by biopsy and tissue culture (Sutoyo, 2009). Fine Needle Aspiration Biopsy (FNAB) is a simple procedure that can be performed on road treatments by doctors or nurses after a short training period (Steel, et al, 1995). This technique is ideal for use in limited resources, including in remote and rural areas. Specimen collection is done simply and safely. In addition, the risk of transmission to those who examine can also be reduced (Mohapatra, \& Janmeja, 2009).

Patients usually present with complaints of enlarged lymph nodes that are slow and painless. In patients who have had TB lymphadenitis for a long time, they will show symptoms of mild fever, 
decreased body weight, fatigue, and some accompanied by night sweats. Coughing is not a typical symptom of lymphadenitis because $9.28 \%$ to $57 \%$ of patients have no symptoms of cough (Mohapatra \& Janmeja, 2009). In TB lymphadenitis, lymph node swelling can occur unilaterally or bilaterally, single or multiple, where these lumps are usually painless and develop slowly in weeks to months, and are most often located in the posterior cervical region and less frequently in the supraclavicular region ( Ferrer, 1998).

\section{RESEARCH METHODS}

This study used a descriptive method with aapproach cross sectional because this research was conducted by collecting data at once at a time (point time approach) (Notoatmodjo, 2010). In this study the population is all lymphadenitis patients who have been diagnosed with cytology fine needle aspiration biopsy and gland histopathology in the Anatomical Pathology Laboratory in Dr. H. Abdoel Moeloek hospital Bandar Lampung in 2015 as many as 271 patients. Researchers used random sampling with a stratified sampling technique that was carried out by identifying the general characteristics of the disease, then determining the strata or layers of the characteristics of the disease, such as age and sex of the sample. The number of samples in this study amounted to 161 samples that have been calculated using the Slovin formula and sampling with the following: Criteria Inclusion criteria of the samples studied were: Patients who had been diagnosed with lymphadenitis with cytological examination and histopathological of lymph gland; The existence of complete data and medical records of lymphadenitis patients in 2015.

\section{RESEARCH RESULTS \& DISCUSSION}

Table 1. Characteristics of Lymphadenitis Based on Etiology ( $\mathrm{N}=161)$

\begin{tabular}{lcc}
\hline \multicolumn{1}{c}{ Variables } & Amount & Percentage \% \\
\hline Lymphadenitis TB & 92 & 57,14 \\
HIV lymphadenitis & 34 & 21,12 \\
Lymphadenitis other microorganisms & 35 & 21,74 \\
Total & 161 & 100.00 \\
\hline
\end{tabular}

Table 2. Characteristics of Patient Age ( $N=161)$

\begin{tabular}{lcccccc}
\hline \multirow{2}{*}{ Age } & \multicolumn{2}{l}{ Lymphadenitis TB } & \multicolumn{2}{l}{ Lymphadenitis HIV } & \multicolumn{2}{l}{ Lymphadenitis Other Microorganisms } \\
\cline { 2 - 7 } & Frequency & $\begin{array}{c}\text { Percentage } \\
(\%)\end{array}$ & Frequency & $\begin{array}{c}\text { Percentage } \\
(\%)\end{array}$ & Frequency & $\begin{array}{c}\text { Percentage } \\
(\%)\end{array}$ \\
\hline $0-4$ th & 0 & 0.0 & 2 & 5.9 & 6 & 17.1 \\
$5-14$ & 3 & 3.3 & 5 & 14.7 & 7 & 20.0 \\
$15-24$ th & 42 & 45.7 & 4 & 11.8 & 10 & 28.6 \\
$25-44$ th & 37 & 40.2 & 9 & 26.5 & 9 & 25,7 \\
$45-64$ th & 10 & 10.9 & 10 & 29.4 & 3 & 8.6 \\
$>65$ th & 0 & 0.0 & 4 & 11.8 & 0 & 0.0 \\
Total & 92 & 100 & 34 & 100 & 35 & 100 \\
\hline
\end{tabular}

Hetti Rusmini' Lecturer in Faculty of Medicine, Malahayati University, Bandar Lampung, Indonesia.

Email: hetti@malahayati.ac.id

Retno Ariza ${ }^{2}$ Medical Doctor in Department of Pulmonology and Respiratory Medicine-Dr. Abdoel Moeloek Hospital,

Bandar Lampung, Indonesia

Nur Rahayu Permana Sari ${ }^{3}$ Student in Medical Education Study Program, Malahayati University, Bandar Lampung, Indonesia. 
Malahayati International Journal of Nursing and Health Science, Volume 02, No.1, March 2019: 14-19 CHARACTERISTICS OF LYMPHADENITIS IN HOSPITALISED PATIENTS

BANDAR LAMPUNG-INDONESIA

Table 3. Characteristics of Lymphadenitis Patients Based on Gender ( $N=161)$

\begin{tabular}{lcccccc}
\hline Gender & \multicolumn{2}{l}{ Lymphadenitis TB } & \multicolumn{2}{l}{ Lymphadenitis HIV } & \multicolumn{2}{c}{ Lymphadenitis Other Microorganisms } \\
\cline { 2 - 7 } & Frequency & $\begin{array}{c}\text { Percentage } \\
(\%)\end{array}$ & Frequency & $\begin{array}{c}\text { Percentage } \\
(\%)\end{array}$ & Frequency & $\begin{array}{c}\text { Percentage } \\
(\%)\end{array}$ \\
\hline Male & 38 & 41.3 & 16 & 47,1 & 19 & 54.3 \\
Women & 54 & 58.7 & 18 & 52.9 & 16 & 45.7 \\
Total & $\mathbf{9 2}$ & $\mathbf{1 0 0}$ & $\mathbf{3 4}$ & $\mathbf{1 0 0}$ & $\mathbf{3 5}$ & $\mathbf{1 0 0}$ \\
\hline
\end{tabular}

Table 4. Characteristics of Lymphadenitis Based on Location of lymph gland Enlargement $(\mathrm{N}=161)$

\begin{tabular}{lcccccc}
\hline \multirow{2}{*}{ Enlargement } & \multicolumn{2}{l}{ Lymphadenitis TB } & \multicolumn{2}{c}{ Lymphadenitis HIV } & \multicolumn{2}{c}{ Lymphadenitis Other Microorganisms } \\
\cline { 2 - 7 } & Frequency & $\begin{array}{c}\text { Percentage } \\
(\%)\end{array}$ & Frequency & $\begin{array}{c}\text { Percentage } \\
(\%)\end{array}$ & $\begin{array}{c}\text { Frequency } \\
(\%)\end{array}$ & $\begin{array}{c}\text { Percentage } \\
(\%)\end{array}$ \\
\hline Neck (colli) & 89 & $96,7 \%$ & 19 & 55.9 & 20 & 57.1 \\
Axilla & 0 & 0.0 & 2 & 5.9 & 1 & 2.9 \\
Submandibular & 3 & 3.3 & 0 & 0.0 & 3 & 8.6 \\
Others & 0 & 0.0 & 13 & 38.2 & 11 & 31,4 \\
Total & $\mathbf{9 2}$ & $\mathbf{1 0 0}$ & $\mathbf{3 4}$ & $\mathbf{1 0 0}$ & $\mathbf{3 5}$ & $\mathbf{1 0 0}$ \\
\hline
\end{tabular}

Based on the results of the research obtained, it is known that the frequency distribution of lymphadenitis had the highest number of tuberculosis lymphadenitis as many as 92 subjects $(57.14 \%), 35$ other microorganism lymphadenitis subjects (21.7\%), and 34 HIV lymphadenitis subjects (21.12\%). This is in accordance with the condition of the country of Indonesia as a developing country and based on WHO data in 2015 stated that Indonesia was ranked second with the largest incidence of TB in the World (WHO, 2015). Besides that, Mycobacterium tuberculosis has properties and endurance that are long enough in the air and can easily infect people who have never been exposed to this bacterium. These bacteria easily enter and multiply in the lungs and can then spread through blood vessels or lymph nodes, so there are very many cases of lymphadenitis caused by Mycobacterium tuberculosis (Susantanaa, 2013).

The data from this study, it is known that the frequency distribution of the age of TB lymphadenitis sufferers from the highest sequence was 15-24 years old as many as 42 subjects (45.7\%), ranked second, aged $25-44$ years as many as 37 subjects (40.2\%), TB lymphadenitis patients at the age of 45-64 years are in the third rank as many as 10 subjects $(10.9 \%)$, while the age of $5-14$ years are 3 subjects $(3.3 \%)$, and no TB lymphadenitis sufferers those aged 0-4 years and> 65 years. This is consistent with the theory that the most common TB lymphadenitis in young adults between the ages of 15 and 45 years is due to increased activity and lack of self-sanitation of the productive age so that the immune system is easily decreased and more quickly infected with Mycobacterium tuberculosis (Jneine et al, 2010). This result is also in accordance with previous research at the Gondar University Hospital in Ethiopia, that the age of most patients was aged 15-24 years (Muluye, et al, 2013). Whereas previous research in Bandung Indonesia, showed that the most age who experienced TB lymphadenitis were ages 20-50 years (Azizi, et al, 2014).

Age frequency distribution of HIV lymphadenitis patients in this study from the highest sequence was

Hetti Rusmini' Lecturer in Faculty of Medicine, Malahayati University, Bandar Lampung, Indonesia.

Email: hetti@malahayati.ac.id

Retno Ariza ${ }^{2}$ Medical Doctor in Department of Pulmonology and Respiratory Medicine-Dr. Abdoel Moeloek Hospital,

Bandar Lampung, Indonesia

Nur Rahayu Permana Sari ${ }^{3}$ Student in Medical Education Study Program, Malahayati University, Bandar Lampung, Indonesia. 
45-64 years old with 10 subjects $(29.4 \%)$, second place 25-55 years old as many as 9 subjects $(26.5 \%)$, age $5-14$ years ranked third, as many as 5 subjects $(14.7 \%)$ with age $>65$ years as many as 4 subjects $(11.8 \%)$, while ages $15-24$ years as many as 4 subjects $(11.8 \%)$, and at the age of $0-4$ years as many as 2 subjects (5.9\%). This is in accordance with previous studies in India that more than 40 (4050 years) are more likely to experience HIV lymphadenitis than those aged 20-40 years, because the age of 40-50 has a lower endurance compared to young age and organs already cannot perform its function perfectly (Thakkar, Ghaisas, \& Singh, 2016). But this is different from the results of research conducted by Neelima, et al. that HIV lymphadenitis is more frequent at the age of 21-40 years because this behavior is relatively young to do something that makes it easier to become infected with the HIV virus, for example by free sex or by exchanging drug needles (Tirumalasetti \& Latha, 2014).

The age distribution of other microorganism lymphadenitis sufferers in this study from the highest sequence was 15-24 years old with 10 subjects $(28.6 \%)$, second place $25-44$ years old with 9 subjects $(25.7 \%)$, age $5-14$ years is ranked third, as many as 7 subjects $(20.0 \%)$, while ages $0-4$ years as many as 6 subjects $(17.1 \%)$, ages $45-64$ years as many as 3 subjects $(8.6 \%)$, and there are no other microorganism lymphadenitis sufferers at the age of $>$ 65 years. These results are consistent with previous studies in Chicago that the age range of 20-40 years is more often affected by other microorganism lymphadenitis than those aged $>40$ years (Bortoletto, et al, 2015), but this result is not in accordance with the theory because lymphadenitis of other microorganisms is more often about age $0-18$ years (Tebruegge, et al, 2016). The gender, that female sex predominated in TB lymphadenitis patients as many as 54 subjects $(58.7 \%)$, while 38 men $(41.3 \%)$. This result is in accordance with the theory that women are more likely to be affected by TB than men because of differences in behavior between women and men and their health status (Manalu, 2010). The results of this study are also the same as Muluye's study in Ethiopia that women were higher in TB lymphadenitis compared to men (Muluye, et al, 2013).

The most frequent sex distribution of HIV lymphadenitis was women, which were 18 subjects $(52.9 \%)$ while men were 16 subjects $(47.1 \%)$. This result is in accordance with the research conducted by Rasmaliah which states that men and women have the chance of the incidence of HIV lymphadenitis which is 1.3:1, explained that men were more affected by HIV lymphadenitis than women because HIV sufferers were more often exposed to homo sexuals (Amin, et al, 2014). The most common frequency distribution of the sexes of microorganism lymphadenitis was male, which was 19 subjects $(54.3 \%)$, while women were 16 subjects (45.7\%). These results are in accordance with the theory that men are more often affected by other microorganism lymphadenitis compared to women because smoking and drinking alcohol can reduce the body's defense system so it is more easily exposed to microorganisms, this result is consistent with previous studies conducted in France and Chicago that men men are more often affected by other microorganism lymphadenitis compared to women (Muluye, et al, 2013; George, et al, 2014).

Besides the distribution of the frequency of age and sex this study also explained the frequency distribution of the location of TB lymphadenitis from the highest sequence was neck (colli region) as many as 89 subjects $(96.7 \%)$, second rank was submandibular as many as 3 subjects (3.3\%), and not in other locations. These results are in accordance with the theory that the neck region (colli region) is more often affected by TB lymphadenitis because the lymph nodes in the neck (colli region) are the first filtration when Mycobacterium tuberculosis enters through droplets, the results of the same study were carried out by Dagnachew muluye in Ethiopia and Asthma jniene in Morocco that the most common locations often affected by TB lymphadenitis are colli regions or neck sections (Muluye, et al, 2013; Jniene, et al, 2010).

The frequency distribution of the location of HIV lymphadenitis in the highest order was 19 subjects $(55.9 \%)$, in locations other than the neck and axilla

Hetti Rusmini' Lecturer in Faculty of Medicine, Malahayati University, Bandar Lampung, Indonesia.

Email: hetti@malahayati.ac.id

Retno Ariza ${ }^{2}$ Medical Doctor in Department of Pulmonology and Respiratory Medicine-Dr. Abdoel Moeloek Hospital,

Bandar Lampung, Indonesia

Nur Rahayu Permana Sari ${ }^{3}$ Student in Medical Education Study Program, Malahayati University, Bandar Lampung, Indonesia. 
for example inguinal and generalized as many as 13 subjects $(38.2 \%)$, while in the axilla there were 2 subjects $(5,9 \%)$. These results are in line with the theory that HIV lymphadenitis more often affects the neck or more precisely in supra clavicula which has a close association with malignancy (Oehadian, 2013). These results are also in accordance with previous studies conducted in India, the colli region which was more often affected by HIV lymphadenitis (Tirumalasetti \& Latha, 2014).

The frequency distribution of the location of other microorganism lymphadenitis from the highest sequence was the neck (colli region) as many as 20 subjects $(57.1 \%)$, in areas other than neck, axilla and sub mandibular as many as 11 subjects $(31.4 \%)$, submandibular as many as 3 subjects ( $8.6 \%$ ), while the axilla was 1 subject $(2.9 \%)$. This result is consistent with the theory that other microorganism lymphadenitis infects more often in the colli region (Oehadian, 2013). This result is also in accordance with the study conducted by Tebruegge, et al. that colli regions are most often affected by other microorganism lymphadenitis (Trebugge, et al, 2016).

\section{CONCLUSION}

Based on the research conducted it can be concluded that the frequency distribution of lymphadenitis sufferers from the highest sequence is tuberculosis lymphadenitis as much as $57.14 \%$, other microorganism lymphadenitis as much as $21.7 \%$, and HIV lymphadenitis as much as $21.12 \%$. The frequency distribution of the age of most TB lymphadenitis sufferers was 15-24 years old as much as $45.7 \%$, while the majority of patients with HIV lymphadenitis were aged $45-64$ years as much as $29.4 \%$, and the age of most microorganism lymphadenitis sufferers was aged 15-24 years as much as $20.0 \%$. The highest frequency distribution of the sex of TB lymphadenitis and HIV were women, namely $58.7 \%$ and $52.9 \%$. Whereas most of the microorganism lymphadenitis in male sex is as much as $54.3 \%$. The most frequent distribution of TB lymphadenitis, HIV and other microorganisms is the neck (colli region) as much as $96 \%, 55.9 \%$, and $57.1 \%$.

\section{REFERENCES}

Amin, Z., Uyainah, A., Yunihastuti, E., \& Djoerban, Z. (2014). Profil Pasien Tb-Hiv Dan Non Tb-Hiv Di RSCM. Buletin penelitian kesehatan, 41(4 Des), 195-199.

Azizi, F. H., Husin, U. A., \& Rusmartini, T. (2014). Gambaran Karakteristik Tuberkulosis Paru Dan Ekstra Paru Di BBKPM Bandung Tahun 2014. Universitas Islam Bandung.

Bortoletto, P., Lyman, K., Camacho, A., Fricchione, M., Khanolkar, A., \& Katz, B. Z. (2015). Chronic granulomatous disease: a large, single-center US experience. The Pediatric infectious disease journal, 34(10), 1110.

Ferrer, R. (1998). Lymphadenopathy: differential diagnosis and evaluation. American family physician, 58(6), 1313-1320.

Georget, E., Gauthier, A., Brugel, L., Verlhac, S., Remus, N., Epaud, R., \& Madhi, F. (2014). Acute cervical lymphadenitis and infections of the retropharyngeal and parapharyngeal spaces in children. BMC Ear, Nose and Throat Disorders, 14(1), 8.

Jniene, A., Soualhi, M., Bouassel, M., Nayme, I., Zahraoui, R., \& Iraqui, G. (2010). Epidemiological, therapeutic and evolutionary profiles in patients with lymph node tuberculosis. Tuberk Toraks, 58(4), 366-374.

Manalu, H. S. P. (2010). Faktor-faktor yang mempengaruhi kejadian TB paru dan upaya penanggulangannya. Jurnal Ekologi Kesehatan, 9(4 Des).

Mohapatra, P. R., \& Janmeja, A. K. (2009). Tuberculous lymphadenitis. J Assoc Physicians India, 57(6), 585590.

Hetti Rusmini' Lecturer in Faculty of Medicine, Malahayati University, Bandar Lampung, Indonesia.

Email: hetti@malahayati.ac.id

Retno Ariza ${ }^{2}$ Medical Doctor in Department of Pulmonology and Respiratory Medicine-Dr. Abdoel Moeloek Hospital,

Bandar Lampung, Indonesia

Nur Rahayu Permana Sari ${ }^{3}$ Student in Medical Education Study Program, Malahayati University, Bandar Lampung, Indonesia. 
Muluye, D., Biadgo, B., Woldegerima, E., \& Ambachew, A. (2013). Prevalence of tuberculous lymphadenitis in Gondar University Hospital, Northwest Ethiopia. BMC Public Health, 13(1), 435.

Notoatmodjo, S. (2010). Metodologi penelitian kesehatan.

Oehadian, A. (2013). Pendekatan diagnosis limfadenopati. Cdk, 40, 727-732.

Price, S. A., \& Wilson, L. M. (2005). Patofisiologi vol 1: konsep klinik proses-proses penyakit. Trans. Pendit $B U$, Hartanto $H$, Wulansari $P$, Mahanani $D A$. Jakarta: EGC.

Steel, B. L., Schwartz, M. R., \& Ramzy, I. (1995). Fine needle aspiration biopsy in the diagnosis of lymphadenopathy in 1,103 patients. Role, limitations and analysis of diagnostic pitfalls. Acta cytologica, 39(1), 76-81.

Susantanaa, E.(2013). Karakteristik Penderita Tuberkulosis Kelenjar yang Dikonfirmasi dengan Sitologi Aspirasi Biopsi di RSUD Dr. Pirngadi Pada Tahun 2013. Karakteristik Penderita Tuberkulosis Kelenjar yang Dikonfirmasi dengan Sitologi Aspirasi Biopsi di RSUD Dr. Pirngadi Pada Tahun 2013.
Sutoyo, E.(2009). Profil Penderita Limfadenopati Servikalis Yang Dilakukan Tindakan Biopsi Aspirasi Jarum Halus Di Instalasi Patologi Anatomi RSUP H. Adam Malik Medan Tahun 2009 (Master's thesis).

Tebruegge, M., Pantazidou, A., MacGregor, D., Gonis, G., Leslie, D., Sedda, L., \& Curtis, N. (2016). Nontuberculous mycobacterial disease in childrenepidemiology, diagnosis \& management at a tertiary center. PloS one, 11(1), e0147513.

Thakkar, K., Ghaisas, S. M., \& Singh, M. (2016). Lymphadenopathy: Differentiation between tuberculosis and other non-tuberculosis causes like follicular lymphoma. Frontiers in public health, 4, 31.

Tirumalasetti, N., \& Latha, P. P. (2014). Lymph nodes cytology in HIV seropositive cases with haematological alterations. The Indian Journal of Medical Research, 139(2), 301.

World Health Organization (Ed.). (2013). Global tuberculosis report 2013. World Health Organization

World Health Organization. (2015). Global tuberculosis report 2015. World Health Organization.

Hetti Rusmini' Lecturer in Faculty of Medicine, Malahayati University, Bandar Lampung, Indonesia.

Email: hetti@malahayati.ac.id

Retno Ariza ${ }^{2}$ Medical Doctor in Department of Pulmonology and Respiratory Medicine-Dr. Abdoel Moeloek Hospital,

Bandar Lampung, Indonesia

Nur Rahayu Permana Sari ${ }^{3}$ Student in Medical Education Study Program, Malahayati University, Bandar Lampung, Indonesia. 